\title{
An epidemiological study of Protein Energy Malnutrition (PEM) among 1-6 years children in rural Lucknow, Uttar Pradesh, India
}

\author{
Ram Milan Prasot ${ }^{1}$, Sudhir Kumar Verma ${ }^{2}$, Saurabh Kashyap ${ }^{3}$, \\ Mukesh Kr. Kanaujiya ${ }^{4}$ \\ ${ }^{I}$ Assistant Professor, Department of Community Medicine, CAREER Institute of Medical Sciences, Ghaila, \\ Lucknow, U.P., India \\ ${ }^{2}$ Assistant Professor, Department of General Medicine, CAREER Institute of Medical Sciences, Ghaila, \\ Lucknow, U.P., India \\ ${ }^{3}$ Assistant Professor, Department of Community Medicine, Integral Institute of Medical Sciences,Lucknow, \\ U.P., India \\ ${ }^{4}$ MSW, Department of Community Medicine, CAREER Institute of Medical Sciences, Ghaila, Lucknow, U.P., \\ India
}

\begin{abstract}
Background: Under-nutrition continues to be a major public health problem in developing countries and various factors are involved in determining the nutritional status of the children. Objectives: To study the prevalence of protein energy malnutrition (PEM) and various socio-demographic factors influencing it, among children (1-6 years) in rural community. Methods: A cross-sectional study was undertaken by house to house visit covering 400 children (1-6 years) from the six villages around the Rural Health Training Centre (RHTC), under department of Community medicine of Carrier Institute of Medical Science, Lucknow, U.P., India.Results: According to Indian Academy of Pediatrics (IAP), the prevalence of PEM was $54.8 \%$ with the proportion of grade I, II and III being 33\%, $18.3 \%$ and 3.5\%, respectively and none of the children was in grade IV under nutrition.The prevalence of underweight was significantly $(p<0.001)$ higher in 1-3 years children (71.2\%) as compared to 3-6 years children (46.6\%). Girls $(61.8 \%)$ were significantly $(p=0.008)$ more malnourishedthan boys $(48.6 \%)$ in all grade of underweight. PEM was significantly $(p=<0.05)$ higher in children belonging to Hindu religion, schedule caste, nuclear family, among $\geq 3$ siblings, illiterate father, lower socioeconomic status, poor housing \& environmental sanitation.Conclusion: The burden of PEM was very high and some important risk factors for it were age, girls, schedule caste, lower socio-economic status, poor condition of housing and environmental sanitation. Therefore, any intervention to prevent and solve the problem of PEM should focus on these high risk groups.
\end{abstract}

Key Words:Malnutrition, Nutritional status, PEM, Under-nutrition

\section{Introduction}

Nearly one in five children under age five in the developing world is underweight (MDG report, 2012) ${ }^{1}$ and it continues to be a primary cause of ill health and mortality among children. The World Health Organization (WHO) has reported hunger and related malnutrition as the greatest single threat to the world's public health. One in every three malnourished children of the world lives in India ${ }^{2}$ and under-nutrition is a major cause in more than half of under-five deaths ${ }^{3}$. In India ${ }^{4}$, around $43 \%$ of under five children were underweight according to the report of third national family health survey (NFHS- 3) conducted during 2005-06 whereas in rural Uttar Pradesh ${ }^{5}$,it was $44.1 \%$. Malnutrition has shown to be an important concern in children because of rapid growth and development. Pre-school children are most vulnerable to the effect of protein energy malnutrition (PEM) and their nutritional status is considered to be a sensitive indicator of community health, so that the present study was conducted to study the epidemiology of protein energy malnutrition among children (1-6 years) in rural Lucknow.

\section{Material \& Methods}

The study setting was the rural area of Chinhat block of Lucknowdistrict which is the field practice area of Rural Health Training Centre (RHTC) under the Department of Community Medicine, Career Institute of Medical Sciences (CIMS), Lucknow, U.P. It carried out in six villages located around the RHTC during 01 July, 2013 to 31 December, 2013. The study was a community based cross-sectional and multi-stage random sampling technique was used for selection of villages. Study participants were all the Children of age group of 1-6 years residing in study area. An optimum sample size for study was obtained by $4 \mathrm{PQ} / \mathrm{L}^{2}$ assuming the protein energy malnutrition (PEM) prevalence $(\mathrm{P})$ of 50\% in children (1-6 years) with $10 \%$ relative precision and $95 \%$ confidence interval. Expecting $10 \%$ family nonresponsive, 440 children were targeted for interview by 
house to house visit. The families who were nonresponsive or children who were not accompanied by their parents/ guardians were excluded from the study.

Detailed information about socio-demographic characteristics such as; age, sex, religion, caste, type of family, numberof siblings, mother's literacy, father's educational level, socioeconomic statusand selected risk factors about the mother's dietary knowledge, utilization of Anganwadi Centre service of complementary food, housing and environmental sanitation were collected on a predesigned and pretested questionnaire and supplemented by physical and anthropometric examination of child. The weight (in $\mathrm{kg}$ ) of the children was measured using bathroom weighing scale and they were with minimal clothing and without footwear when measurements were taken. Socio-economic status was determined by using modified Prasad's scale (Prasad's SES classification, $2013)^{6}$. For grading of PEM, Indian Academy of Pediatrics (IAP) classification was used. Data was entered in the MS Excel 2007 and analysis was done in SPSS 16. Statistical value (p- value) was calculated using chisquare tests. Children identified with unhealthy conditions/diseases were examined and treated. Participants who required further management and follow up were referred to CIMS Lucknow.

\section{Results}

Table 1 shows that out of 400 children (1-6 years), overall prevalence of protein energy malnutrition (PEM) was $54.8 \%$. The children of age group $1-3$ years $(71.2 \%)$ were significantly $(\mathrm{p}<0.001)$ more malnourished as compared to 3-6 years age group $(46.6 \%)$. Regarding the sex, girls $(61.8 \%)$ were significantly $(p=0.008)$ more malnourished in all grade of PEM (Table 2) compare to boys (48.6\%).

Table 3 shows that there was a significant association $(\mathrm{p}<0.001)$ between PEM and religion. More than two third $(70.5 \%)$ of children were Hindu while the rest were Muslim and the Hindu children $(62.4 \%)$ were more malnourished than the Muslim children (36.4\%). Regarding the caste in Hindu, 36.2\% children belonged to schedule caste in which more than three fourth $(86.3 \%)$ were significantly $(\mathrm{p}<0.001)$ malnourished as compared to general caste children $(27.1 \%)$. The majority $(53 \%)$ of children belonged to nuclear family while the rest $(47 \%)$ to joint family and the prevalence of PEM was significantly $(\mathrm{p}=0.003) 61.8 \%$ and $46.8 \%$ among them, respectively. The association between PEM and number of siblings was found to be significant $(p<0.001)$ and the prevalence of PEM was observed higheramong children $(61.9 \%)$ of $\geq 3$ siblings compare to children (45.4\%) with 1-2 siblings.

Majority (59\%) of children of illiterate mother were malnourished as compared to children (50.5\%) of literate mother but an insignificant $(\mathrm{p}=0.088)$ association was found between the prevalence of PEM in children and their mother's literacy whereasa significant $(\mathrm{p}<0.001)$ association was found between PEM in children and their father's educational level and it was observed that $61.9 \%$ children were affected with PEM whose father's educational level was illiterate or primary school. In the present study, there was no any child of socioeconomic class I and Children belonging to lower socio-economic class were significantly $(\mathrm{p}=0.009)$ poorly nourished than those belong to upper socio-economic class.

Table 4 shows that more than half (51\%) children's mother has inadequate knowledge about diet to her child and prevalence of PEM was found to be insignificantly ( $\mathrm{p}=0.643)$ higher $(55.9 \%)$ among them. There was also an insignificant difference $(\mathrm{p}=0.402)$ was found between PEM in children and utilization of Anganwadi services by them and majority $(56.3 \%)$ of children were malnourished who were not having complementary food from Anganwadi Centre. Statistically a significant association $(\mathrm{p}<0.001)$ was found between PEM and condition of housing and environmental sanitation. Nearly three fourth $(72.6 \%)$ children were affected with PEM who were living in poor conditions of housing and environmental sanitation.

Table 1: Age and sex wise prevalence of PEM in children among 1-6 years age group (n=400).

\begin{tabular}{|l|c|c|c|c|c|c|}
\hline \multirow{2}{*}{ Age (years) } & \multicolumn{2}{|c|}{ Male } & \multicolumn{2}{c|}{ Female } & \multicolumn{2}{c|}{ Total } \\
\cline { 2 - 6 } & $\begin{array}{c}\text { Children } \\
\text { studied }\end{array}$ & Underweight & $\begin{array}{c}\text { Children } \\
\text { studied }\end{array}$ & Underweight & $\begin{array}{c}\text { Children } \\
\text { studied }\end{array}$ & Underweight \\
\hline $\mathbf{1 - 3}$ & $68(51.5)$ & $45(66.2)$ & $64(48.5)$ & $49(76.6)$ & $132(33.0)$ & $94(71.2)$ \\
\hline $\mathbf{3 - 6}$ & $146(54.5)$ & $59(40.4)$ & $122(45.5)$ & $66(54.1)$ & $268(67.0)$ & $125(46.6)$ \\
\hline Total & $214(53.5)$ & $104(48.6)$ & $186(46.5)$ & $115(61.8)$ & $400(100)$ & $219(54.8)$ \\
\hline
\end{tabular}

Figures in parenthesis show percentages.

Age- $\chi^{2}=21.551, \mathrm{p}<0.001 \quad$ Sex $-\chi^{2}=7.03, \mathrm{p}=0.008$ 
Table 2: Prevalence of Underweight among Children (1-6 years) according to severity $(n=400)$

\begin{tabular}{|l|c|c|c|}
\hline $\begin{array}{l}\text { Prevalence of PEM } \\
\text { IAP Classification) }\end{array}$ & Male & Female & Total \\
\hline Normal weight & $110(60.8)$ & $71(39.2)$ & $181(45.2)$ \\
\hline Underweight & & & $132(33.0)$ \\
\hline Grade I (mild) & $72(54.5)$ & $60(45.5)$ & $73(18.3)$ \\
\hline Grade II (moderate) & $29(39.7)$ & $44(60.3)$ & $14(3.5)$ \\
\hline Grade III (severe) & $3(21.4)$ & $11(78.6)$ & $400(100)$ \\
\hline Total & $214(53.5)$ & $186(46.5)$ & \\
\hline
\end{tabular}

Figures in parenthesis show percentages

Table 3: Prevalence of Underweight among children (1-6 years) in relation to socio-demographic factors $(\mathrm{n}=\mathbf{4 0 0})$

\begin{tabular}{|c|c|c|c|c|}
\hline Variables & Normal weight & Under weight & Total & Significance \\
\hline \multicolumn{5}{|l|}{ Religion } \\
\hline Hindu & $106(37.6)$ & $176(62.4)$ & $282(70.5)$ & \multirow{2}{*}{$\begin{array}{c}\chi^{2}=22.648 \\
p<0.001\end{array}$} \\
\hline Muslim & $75(63.6)$ & $43(36.4)$ & $118(29.5)$ & \\
\hline \multicolumn{5}{|l|}{ Caste (in Hindu) } \\
\hline Schedule caste & $14(13.7)$ & $88(86.3)$ & $102(36.2)$ & \multirow{3}{*}{$\begin{array}{c}\chi^{2}=71.505 \\
p<0.001\end{array}$} \\
\hline Others backward class & $30(31.6)$ & $65(68.4)$ & $95(33.7)$ & \\
\hline General class & $62(72.9)$ & $23(27.1)$ & $85(30.1)$ & \\
\hline \multicolumn{5}{|l|}{ Type of family } \\
\hline Nuclear & $81(38.2)$ & $131(61.8)$ & $212(53.0)$ & \multirow{2}{*}{$\begin{array}{l}\chi^{2}=9.03 \\
\mathrm{p}=0.003\end{array}$} \\
\hline Joint & $100(53.2)$ & $88(46.8)$ & $188(47.0)$ & \\
\hline \multicolumn{5}{|l|}{ Number of siblings } \\
\hline $1-2$ & $95(54.6)$ & $79(45.4)$ & $174(43.5)$ & \multirow{2}{*}{$\begin{array}{c}\chi^{2}=10.862 \\
p<0.001\end{array}$} \\
\hline$\geq 3$ & $86(38.1)$ & $140(61.9)$ & $226(56.5)$ & \\
\hline \multicolumn{5}{|l|}{ Mother's literacy } \\
\hline Illiterate & $82(41.0)$ & $118(59.0)$ & $200(50.0)$ & \multirow{2}{*}{$\begin{array}{l}\chi^{2}=2.916 \\
\mathrm{p}=0.088\end{array}$} \\
\hline Literate & $99(49.5)$ & $101(50.5)$ & $200(50.0)$ & \\
\hline \multicolumn{5}{|l|}{ Father's education } \\
\hline Illiterate \& Primary school & $93(38.1)$ & 151(61.9) & $244(61.0)$ & \multirow{2}{*}{$\begin{array}{c}\chi^{2}=12.857 \\
\mathrm{p}<0.001\end{array}$} \\
\hline Middle school \& above & $88(56.4)$ & $68(43.6)$ & $156(39.0)$ & \\
\hline \multicolumn{5}{|l|}{ Socioeconomic Status" } \\
\hline II & $27(69.2)$ & $12(30.8)$ & $39(9.8)$ & \multirow{4}{*}{$\begin{array}{l}\chi^{2}=11.54 \\
\mathrm{p}=0.009\end{array}$} \\
\hline III & $48(47.1)$ & $54(52.9)$ & $102(25.5)$ & \\
\hline IV & $59(42.8)$ & $79(57.2)$ & $138(34.5)$ & \\
\hline $\mathrm{V}$ & $47(38.8)$ & $74(61.2)$ & $121(30.3)$ & \\
\hline
\end{tabular}

Figures in parenthesis show percentages

*Modified B. G. Prasad's Classification

Table 4: Prevalence of underweight among 1-6 year children in relation to selected risk factors $(n=400)$

\begin{tabular}{|c|c|c|c|c|}
\hline Risk factors & Normal weight & Underweight & Total & significance \\
\hline \multicolumn{5}{|c|}{ Dietary knowledge to Mother } \\
\hline Adequate & $91(46.4)$ & $105(53.6)$ & $196(49.0)$ & \multirow{2}{*}{$\begin{array}{l}\chi^{2}=0.215 \\
p=0.643\end{array}$} \\
\hline Inadequate & $90(44.1)$ & $114(55.9)$ & $204(51.0)$ & \\
\hline \multicolumn{5}{|c|}{ Utilization of Anganwadi Centre } \\
\hline Yes & $71(48.0)$ & $77(52.0)$ & $148(37.0)$ & \multirow{2}{*}{$\begin{array}{l}\chi^{2}=0.703 \\
\mathrm{p}=0.402\end{array}$} \\
\hline No & $110(43.7)$ & $142(56.3)$ & $252(63.0)$ & \\
\hline \multicolumn{5}{|c|}{ Housing \& Environmental sanitation } \\
\hline Poor & $29(27.4)$ & $77(72.6)$ & $106(26.5)$ & \multirow{3}{*}{$\begin{array}{c}\chi^{2}=59.072 \\
p<0.001\end{array}$} \\
\hline Satisfactory & $60(35.7)$ & $108(64.3)$ & $168(42.0)$ & \\
\hline Good & $92(73.0)$ & $34(27.0)$ & $126(31.5)$ & \\
\hline
\end{tabular}

Figures in parenthesis show percentages

\section{Discussion}

In the present study, the prevalence of protein energy malnutrition (PEM) and its relation to various epidemiological factors among 400 children was assessed on the basis of weight for age, using IAP classification. As per study, more than half of children were malnourished which is in accordance to the previous study of Singh et al. (2012) ${ }^{7}$ done in rural Meerut district of India among 406 children (1-6 years) and revealed that $57.4 \%$ children were malnourished whereas another study ${ }^{8}$ reported that prevalence of underweight among children under six years of age was $53.3 \%$ in Uttar Pradesh, a largest populated state of India. Nearly three fourth of children of 1-3 years age group were malnourished which is similar to finding of a study done by Chakraborty et al. (2006) ${ }^{9}$ in rural Jhansi who observed that malnutrition was significantly $(\mathrm{p}=<0.05)$ more prevalent in the younger age (1-3 yrs) group children (80.9\%). Regarding the sex, nearly two third of female children $(61.8 \%)$ in comparison to male children $(48.6 \%)$ were more malnourished. In a previous 
study, done by Stalin P et al. (2013) ${ }^{10}$ among 563 under five children in rural Tamil Nadu, found a significant association between malnutrition and sex of children with prevalence of underweight, $62.6 \%$ and $44 \%$ among female and male children, respectively.

As per study, only $45.2 \%$ children were of normal weight whereas $33 \%, 18.3 \%$ and $3.5 \%$ children of grade I, II and III were malnourished which is in accordance to the previous study ${ }^{8}$ that reported, $46.69 \%$ children were of normal weight but $32.09 \%, 20.24 \%$ and $0.98 \%$ of grade I, II, and III/IV under six children were of underweight in U.P., respectively. In this study, nearly two third of Hindu children were affected with PEM whereas only one third of Muslim children were malnourished which is contrary to the NFHS-III (2005$06)^{5}$,that reported about all the children under five of both religion were almost equally affected with PEM. In Hindu, the schedule caste children were more malnourished as compare to general caste children which is in accordance to previous study done by Singh et al. (2012) ${ }^{7}$ that reported, nearly two third (64.9\%) children of schedule caste were insignificantly $(\mathrm{p}>0.05)$ malnourished.

Children belonging to nuclear family were more affected with PEM than the joint family which is similar to findings of Singh et al. (2012) ${ }^{7}$ that reported $63.8 \%$ and $52.9 \%$ children of nuclear and joint family were malnourished, respectively. It may be due to the reason that children in the joint family are nutritionally better cared as there is tendency to share the food with the children by all the family members. The prevalence of PEM was found to be higher in those children who have $\geq 3$ siblings compare to children with 1-2 siblings which is in accordance to findings of Sengupta et al. (2010) ${ }^{11}$ and Bhavsar et al. (2012) ${ }^{12}$, that reported majority of children, $51.7 \%$ and $67.2 \%$ were malnourished who have $\geq 3$ siblings, respectively.

Literate mothers adopt many improved behaviors related to maternal and child health care, feeding and eating practices which ultimately affect the nutritional status of children. As per study, more than half $(59 \%)$ children of illiterate mother as compared to children of literate mother were malnourished. Similar result that the prevalence of PEM among children decreased with increasing mother's literacy was reported by NFHS-III $(2005-06)^{5}$ and Singh et al. $(2012)^{7}$. On the other hand the prevalence of PEM in children was also found to be significantly higher whose father's educational level was illiterate or primary school. A study done by Bhavsar et al. (2012) ${ }^{12}$ in Mumbai urban slum also revealed that nearly two third children under six of illiterate/primary school father were malnourished.It was observed that the socio economic status of the family improved the nutritional status of the children. A study done by Stalin P et al $(2013)^{10}$ in rural Kancheepuram, Tamil Nadu found that nearly two third $(63.4 \%)$ and half $(47.2 \%)$ children in category IV and V were significantly $(\mathrm{p}<0.05)$ malnourished, respectively whereas in another study by Bhavsar et al. $(2012)^{12}$ observed that most $(80.2 \%)$ of children belonging to lower class (IV+ V) were significantly malnourished.

In the present study, the majority (55.9\%) of children who were malnourished, their mother did not have adequate knowledge regarding the diet requirements of her child and the nutritional value of food items. This is similar to the findings from a study done by Joshi et al $(2011)^{13}$ in western Nepal that reported, 58\% children (4-14 yrs) were malnourished whose mother has inadequate knowledge about diet. In Uttar Pradesh although majority $(76.2 \%)$ of under six childrenwere covered by an AWC but only $14.7 \%$ of children received service of supplementary food (NFHS-III) ${ }^{5}$. As per the study, more than half children were malnourished who were not utilizing service of complementary food which is in accordance to the study of Stalin P et al. $(2013)^{10}$ who reported that more than half $(54.8 \%)$ of children were malnourished. The condition of housing and environmental sanitation determines health status of children as well as community. In present study, it was observed that more than two third children were affected with PEM when housing and environmental sanitation conditions were poor while when environmental and sanitary conditions were good prevalence of PEM was uncommon which is comparable with findings of Singh et al. $(2012)^{7}$ in which most $(81.4 \%)$ of children were significantly $(\mathrm{p}<0.05)$ malnourished who were living in condition of poor housing and environmental sanitation.

\section{Conclusion}

The present study shows that more than half (54.8\%) of children (1-6 years) were underweight and prevalence of PEM was higher in children of 1-3 years of age group, female sex, Hindu religion, schedule caste, nuclear family, children having $\geq 3$ siblings, illiterate father, lower socioeconomic status, poor housing and sanitation. The study suggests intensification of Integrated Child Development Services (ICDS) with multisectoral strengthening that can be achieved by the help of Accredited Social Health Activist (ASHA), Aganwadi Worker (AWW), Auxillary Nurse Midwife (ANM) and local village self help groups. The extent of malnutrition can be countered by educating the parents with respect to basic nutritional requirements of their children and encouraging them to consume locally available low cost foods.

\section{Acknowledgements}

We would like to thank our institute for providing logistic supports and our staff for helping us to conduct this study. 


\section{References}

[1] Millennium Development Goals (MDG) report 2012. Available at: http://www.un.org/millenniumgoals/reports.shtml

[2] UNICEF India. The Children - Nutrition. Available at: http://www.unicef.org/india/children_2356.htm

[3] Levels \& trends in Child Mortality report 2011. Estimates developed by the UN inter-agency group for child mortality estimation. Available at: http://www.unicef.org/media/files/Child_Mortality_Report_2011_Final.pdf

[4] National Family Health Survey (NFHS-3), India, 2005-06. Ministry of Health and Family Welfare, Govt. of India, International Institute for Population Sciences Deonar, Mumbai. Available at: http://www.indiahealthstat.com

[5] National Family Health Survey (NFHS-3), U.P. 2005-06. Fact sheet Uttar Pradesh. International institute of population sciences, Deonar, Mumbai, India.

[6] Shankar Reddy Dudala and N Arlappa. An updated Prasad's socio economic status classification.Int J Res Dev Health; April 2013; Vol. 1(2).

[7] AK Singh, Seemajain, M Bhatnagar, JV Singh, SK Garg, H Chopra, SK Bajpai. Socio-demographic determinants of malnutrition among children of 1-6 Years of age in rural Meerut. IOSR Journal of Dental and Medical Sciences; Nov.- Dec 2012; Vol. 3, Issue 3: $37-40$

[8] Freedom from hunger for children under six. An outline for save the children and civil society involvement in childhood under nutrition in India, April 2009; 4th Floor, Farm Bhavan, Nehru Place New Delhi.

[9] S Chakraborty, SB Gupta, B Chaturvedi, SK Chakraborty. A Study of Protein Energy Malnutrition (PEM) in Children (0 to 6 years) in a Rural Population of Jhansi District (U.P.) Indian Journal of Community Medicine; Oct-Dec, 2006; Vol. 31 , No. 4.

[10] P Stalin, Joy Bazroy, Dinesh Dimri, Zile Singh, V Senthilvel, S Sathyanarayanan. Prevalence of underweight and its risk factors among under five children in a rural area of Kancheepuram district in Tamil Nadu. IOSR Journal of Dental and Medical Sciences; Jan.- Feb. 2013, Vol. 3, Issue 6: 71-74.

[11] Sengupta, Paramita., Philip, Nina and Benjamin, A. I. Epidemiological correlates of under-nutrition in under-5years children in an urban slum of Ludhiana. Health and Population: Perspectives and Issues 2010, Vol. 33 (1), 1-9.

[12] SaiprasadBhavsar, H Mahajan, R Kulkarni. Maternal \& environmental factors affecting the nutritional status of children in Mumbai urban slum. International Journal of Scientific and Research Publications. Nov. 2012; Vol. 2, Issue 11.

[13] HS Joshi, R Gupta, MC Joshi, V Mahajan.Determinants of nutritional status of school children, western region of Nepal. NJIRM, .Jan-March 2011; Vol. 2(1): 10. 